\title{
Aplikasi Sistem Akuntansi Rekapitulasi Pendapatan pada Perusahaan Daerah Air Minum (PDAM) Tirtauli Pematangsiantar
}

\author{
Sindi Raharjo Tanjung ${ }^{1}$, Dedi Suhendro ${ }^{2}$ \\ Program Studi Komputerisasi Akuntansi, AMIK Tunas Bangsa Pematangsiantar \\ Jalan Jend. Sudirman Blok A No 1,2,3 Pematangsiantar \\ sindiraharjo228@gmail.com \\ dedi.sulamiktunasbangsa.ac.id
}

\begin{abstract}
Abstact - The Tirtauli Pematangsiantar Regional Water Company (PDAM) is classified as a state-owned company that has operational objectives to meet the needs of the community. Revenues at the Tirtauli Regional Water Company (PDAM) are divided into two, namely water revenues and non-water revenues. Regional income recapitulation Tirtauli Pematangsaiantar still uses Microsoft Excel application where the application is still often an error in revenue recapitulation. Based on this, the authors designed a recapitulation income accounting system application program using Microsoft Basic Net and MySQL database to produce applications better than those running. Application of income recapitulation accounting system using Microsoft Visual Basic Net is designed to produce a better application using a MySQL database designed to perform database manipulation processes with various facilities. The purpose of the authors designed the application to facilitate the User in recapitulation of income with the Visual Basic Net application system so that it can help or simplify the process of inputing income recapitulation.
\end{abstract}

Keywords : Application, Revenue Recapitulation, Microsoft Visual Basic Net, MySQL Database.

Abstrak - Perusahaan Daerah Air Minum (PDAM) Tirtauli Pematangsiantar digolongkan sebagai perusahaan negara yang memiliki tujuan operasional untuk memenuhi kebutuhan masyarakat. Pendapatan pada Perusahaan Daerah Air Minum (PDAM) Tirtauli terbagi menjadi dua, yaitu penerimaan air dan pendapatan non-air. Rekapitulasi pendapatan perusahaan Daerah Air Minum (PDAM) Tirtauli Pematangsaiantar masih menggunakan aplikasi Microsoft Excel di mana aplikasi masih sering kesalahan dalam rekapitulasi pendapatan. Berdasarkan hal ini, penulis merancang program aplikasi sistem akuntansi pendapatan rekapitulasi dengan menggunakan Microsoft Basic Net dan database MySQL untuk menghasilkan aplikasi lebih baik dibandingkan yang sedang berjalan. Aplikasi sistem akuntansi rekapitulasi pendapatan menggunakan Microsoft Visual Basic Net dirancang untuk menghasilkan suatu aplikasi yang lebih baik dengan menggunakan database MySQL yang didesain untuk melakukan proses manipulasi database dengan berbagai fasilitas. Tujuan penulis merancang aplikasi untuk mempermudah $U$ ser dalam melakukan rekapitulasi pendapatan dengan sistem aplikasi Visual Basic Net sehingga dapat membantu atau mempermudah proses penginputan rekapitulasi pendapatan.

Kata Kunci : Aplikasi, Rekapitulasi Pendapatan, Microsoft Visual Basic Net, Database MySQL.

\section{Pendahuluan}

Air salah satu unsur yang vital dalam kehidupan manusia Ketersediaan air didunia termasuk di Indonesia ini begitu melimpah, namun yang dapat dikomsumsi oleh manusia untuk keperluan air minum sangatlah sedikit. Air merupakan bahan alam yang diperlukan untuk kehidupan manusia, hewan dan tanaman yaitu sebagai media pengangkutan zat-zat makanan, juga merupakan sumber energi serta berbagai keperluan lainnya [1]. Air termasuk kedalam kebutuhan dasar sehingga sangat penting bagi manusia, karena manusia tidak dapat bertahan hidup tanpa air, terutama sebagai air minum [2].
Dari total jumlah air yang tersedia, hanya lima persen saja yang tersedia sebagai air minum, sedangkan sisanya adalah air laut. Selain itu, kecenderungan yang terjadi sekarang ini adalah berkurangnya ketersediaan air bersih itu dari hari ke hari. Bumi, air dan kekayaan alam yang terkandung didalamnya dikuasai oleh negara dan dipergunakan untuk sebesar-besar kemakmuran rakyat [3]. Pengembangan Sistem Penyediaan Air Minum adalah kegiatan yang dilakukan terkait dengan ketersediaan sarana dan prasarana dalam rangka memenuhi kuantitas, kualitas, dan kontinuitas Air Minum yang meliputi pembangunan baru, peningkatan, dan perluasan. Perusahaan Daerah Air Minum yang selanjutnya disingkat PDAM adalah Badan 
Usaha Milik Daerah yang bergerak di bidang pelayanan air minum [4]. Pengelolaan Sistem Penyediaan Air Minum adalah kegiatan yang dilakukan terkait dengan kemanfaatan fungsi sarana dan prasarana terbangun yang meliputi operasi dan pemeliharaan, perbaikan, peningkatan sumber daya manusia, serta kelembagaan (PP RI No. 122 Tahun 2015) oleh karena adanya pemeliharaan, perbaikan, peningkatan sumber daya manusia, serta kelembagaan pemerintah menetapkan tarif air minum kepada para pelanggan [5]. Tarif air minum PDAM yang selanjutnya disebut tarif adalah kebijakan harga jual air minum dalam setiap meter kubik (m3) atau satuan volume lainnya sesuai kebijakan yang ditentukan Kepala Daerah dan PDAM yang bersangkutan (Peraturan Menteri dalam Negeri Nomor 23 Tahun 2006) [6]. Untuk memenuhi ekspektasi pelanggan tersebut Perusahaan Daerah Air Minum (PDAM) Tirtauli Pematangsiantar harus menyalurkan air bersih yang layak dari segi kuantitas, kualitas dan kontinuitas.

Setelah penulis melakukan penelitian pada Perusahaan Daerah Air Minum (PDAM) Tirtauli Pematangsiantar sistem akuntansi rekapitulasi pendapatan yang ada pada perusahaan tersebut masih menggunakan sistem rekapitulasi pendapatan secara manual pada aplikasi Microsoft Excel dimana pada Microsoft Excel sering terjadi kesalahan dalam proses penginputannya.

Oleh sebab itu, penulis ingin merancang satu program khusus untuk sistem akuntansi rekapitulasi pendapatan dengan menggunakan Visual Basic Net dan Database MySQL. Tujuan penetian adalah untuk mempermudah User dalam melakukan rekapitulasi pendapatan dengan sistem aplikasi Visual Basic Net. Merancang dan membuat aplikasi pemograman dengan database sehingga dapat membantu atau mempermudah proses penginputan rekapitulasi pendapatan.

Aplikasi adalah suatu subkelas dari suatu perangkat lunak komputer yang memanfaatkan kemampuan komputer secara langsung untuk melakukan suatu tugas yang diinginkan pengguna. Aplikasi dapat juga dikatakan sebagai penerjemah perintah-perintah yang dijalankan pengguna komputer untuk diteruskan ke atau diproses oleh perangkat keras. Aplikasi merupakan program yang secara langsung dapat melakukan proses-proses yang digunakan dalam komputer oleh pengguna. Aplikasi merupakan kumpulan dari file-file tertentu yang berisi kode program yang menghubungkan antara pengguna dan perangkat keras computer [7].

Sistem merupakan kumpulan elemen yang saling berhubungan satu sama lain yang membentuk satu kesatuan dalam usaha mencapai suatu tujuan. Di dalam perusahaan, yang dimaksud elemen dari sistem adalah departemen departemen internal, seperti persediaan barang mentah, produksi, persediaan barang jadi, promosi, penjualan, keuangan, personalia; serta pihak eksternal seperti supplier dan konsumen yang saling terkait satu sama lain dan membentuk satu kesatuan usaha [8].
Perkembangan akuntansi dalam konteks sosial dan praktik budaya yang kian beragam semakin mengukuhkan eksistensi paradigma kualitatif [9]. Sebuah proses mencatat, mengklasifikasi, meringkas, mengolah dan menyajikan data, transaksi serta dalam kejadian yang berhubungan dengan keuangan sehingga akuntansi merupakan proses mencatat, mengklasifikasi, meringkas, mengolah dan menyajikan data, transaksi serta dalam kejadian yang berhubungan dengan keuangan yang digunakan oleh orang yang menggunakannya dengan mudah dimengerti dalam pengambilan suatu keputusan serta tujuan lainnya. Akuntansi (accounting) adalah suatu disiplin ilmu tentang informasi penting sehingga memungkinkan adanya pelaksanaan dan penilaian jalannya perusahaan secara efisien [10].

\section{Metode Penelitian}

\section{A. Tahapan-Tahapan Penelitian}

Tahapan-tahapan penelitian merupakan proses jalannya penelitian, dari tahapan ini tergambar jelas apa yang akan dilakukan mulai dari awal sampai akhir penelitian. Tahapan penelitian dapat terlihat pada gambar 1dibawah ini:

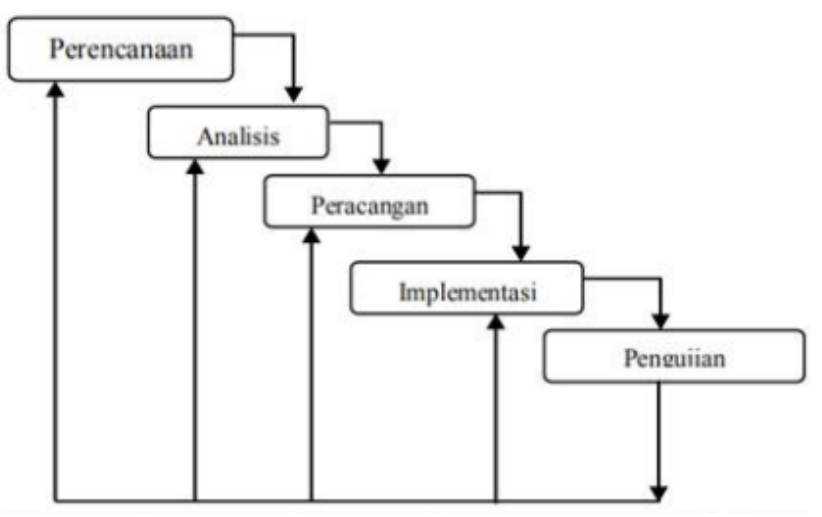

Gambar 1. Tahapan penelitian

1. Tahapan Perencanaan bertujuan untuk memberi rambu-rambu dalam mengembangkan aplikasi agar sesuai dengan tujuan penggunaanya juga dilakukan pembatasan atas apa yang boleh dan tidak boleh dilakukan pada pembuatan aplikasi

2. Pada tahap ini dilakukan analisis terhadap software agar dapat dipahami, perangkat lunak seperti apa yang dibutuhkan oleh user yaitu dengan cara merancang tampilan aplikasi. Analisis bertujuan untuk mendapatkan pemahaman secara keseluruhan tentang aplikasi yang akan dikembangkan berdasarkan masukan dari calon pengguna

3. Pada tahap ini dilakukan desian sistem dengan membuat perancangan sementara yang berfokus pada membuat input dan format output.

4. Setelah melalui tahapan perencanaan, analisis dan perancangan, maka apliksi siap diimplementasikan. 
Pada tahapan implementasi dilaksanakan beberapa tugas, antara lain, implementasi desain ke dalam komponen-komponen source, code, script, executable dan sebagainya, kemudian menyempurnakan arsitektur dan mengintegrasikan komponen-komponen (mengkompile dan link ke dalam satu atau lebih executable) untuk integrasi dan testing system. Terakhir sebelum aplikasi resmi digunakan, dilaksanakan tahapan pengujian.

5. Pada tahapan pengujian, aplikasi diuji untuk menentukan apakah sudah mampu menjalankan semua operasi sesuai tahapan perencanaan dan analisis.

\section{III.HASIL DAN PEMBAHASAN}

\section{A. Analisis Sistem}

Analisis dalam Perancangan Sistem Akuntansi Rekapitulasi Pendapatan pada Perusahaan Daerah Air Minum (PDAM) Tirtauli kota pematangsiantar, penulis menggunakan 5 tabel tahapan yang dilakukan untuk menganalisis sistem yaitu :

\section{Tabel Admin}

Tabel admin merupakan tabel untuk admin Login dan Log Out di program ini. Data pada tabel ini merupakan aturan bahwa satu user mempunyai satu password, sehingga username merupakan Primary Key. Dapat dilihat pada tabel 1 dibawah ini :

TABEL I

TABEL ADMIN

\begin{tabular}{|l|c|l|l|}
\hline Field Name & Data Type & Constraint & Keterangan \\
\hline Username & Varchar (20) & Primary Key & Nama User \\
\hline Password & Varchar (20) & Not null & Password \\
\hline Nama & Varchar (35) & Not null & Nama \\
\hline Alamat & Varchar (50) & Not null & Alamat \\
\hline
\end{tabular}

\section{Tabel Pelanggan}

Tabel pelanggan merupakan tabel yang akan menyimpan data-data pelanggan. Tabel pelanggan berisi 4 field. Dapat dilihat pada tabel 2 dibawah ini : Tabel II Tabel Pelanggan

\begin{tabular}{|l|l|l|l|}
\hline Field Name & Data Type & Constraint & Keterangan \\
\hline KdPelanggan & Char (10) & Primary Key & Kd Pelanggan \\
\hline NmPelanggan & Varchar (35) & Not null & Nm Pelanggan \\
\hline Alamat & Varchar (35) & Not Null & Alamat \\
\hline Jenkel & Varchar (15) & Not Null & Jenis Kelamin \\
\hline
\end{tabular}

3. Tabel Pegawai

Tabel pegawai marupakan tabel yang akan menyimpan data-data pegawai. Tabel pegawai berisi 4 field. Dapat dilihat pada tabel 3 dibawah ini :

TABEL III

TABEL PEGAWAI

\begin{tabular}{|l|l|l|l|}
\hline Field Name & Data Type & Constraint & Keterangan \\
\hline KdPegawai & Char (10) & Primary Key & Kd Pegawai \\
\hline NmPegawai & Varchar (35) & Not null & Nm Pegawai \\
\hline Alamat & Varchar (35) & Not null & Alamat \\
\hline
\end{tabular}

\begin{tabular}{|l|l|l|l|}
\hline Jenkel & Varchar (15) & Not Null & Jenis Kelamin \\
\hline
\end{tabular}

\section{Tabel Golongan}

Tabel golongan merupakan tabel yang akan menyimpan data-data golongan. Tabel golongan berisi 4 field. Dapat dilihat pada tabel 4 dibawah ini : TABEL IV

TABEL GOLONGAN

\begin{tabular}{|l|l|l|l|}
\hline Field Name & Data Type & Constraint & Keterangan \\
\hline KdGol & Char (10) & Primary Key & Kd Golongan \\
\hline NmGol & Varchar (50) & Not Null & Nm Golongan \\
\hline Tarif Gol & Char (10) & Not Null & Tarif Golongan \\
\hline ByPerawatan & Char (10) & Not Null & Tarif Perawatan \\
\hline
\end{tabular}

5. Tarif Air

Tabel tarif air merupakan tabel yang akan menyimpan data-data tarif air. Tabel tarif air berisi 13 field. Dapat dilihat pada tabel 5 dibawah ini :

TABEL V

TABEL TARIF AIR

\begin{tabular}{|l|l|l|l|}
\hline \multicolumn{1}{|c|}{ Field Name } & \multicolumn{1}{|c|}{ Data Type } & Constraint & \multicolumn{1}{|c|}{ Keterangan } \\
\hline KdTarif & Char (10) & Primary Key & Kd Tarif Air \\
\hline Tanggal & Date Time & Not Null & Tanggal \\
\hline KdPegawai & Char (10) & Foreign Key & Kd Pegawai \\
\hline NmPegawai & Varchar (30) & Not Null & Nm Pegawai \\
\hline KdPelanggan & Char (10) & Foreign Key & Kd Pelanggan \\
\hline NmPelanggan & Varchar (50) & Not Null & Nm Pelanggan \\
\hline KdGolongan & Char (10) & Foreign Key & Kd Golongan \\
\hline NmGolongan & Varchar (30) & Not Null & Nm Golongan \\
\hline Pemakaian & Char (20) & Not Null & Pemakaian \\
\hline Ttl Pemakaian & Char (20) & Not Null & Ttl Pemakaian \\
\hline ByPerawatan & Money (20) & Not Null & By Perawatan \\
\hline ByAdmin & Money (20) & Not Null & By Admin \\
\hline Denda & Money (20) & Not Null & Denda \\
\hline Total & Money (20) & Not Null & Total \\
\hline
\end{tabular}

Analisis sistem bertujuan untuk memenuhi kebutuhan kepada pemakai dan memberikan gambaran yang jelas dari sistem yang akan dibagun seperti gambar 2 berikut ini : 


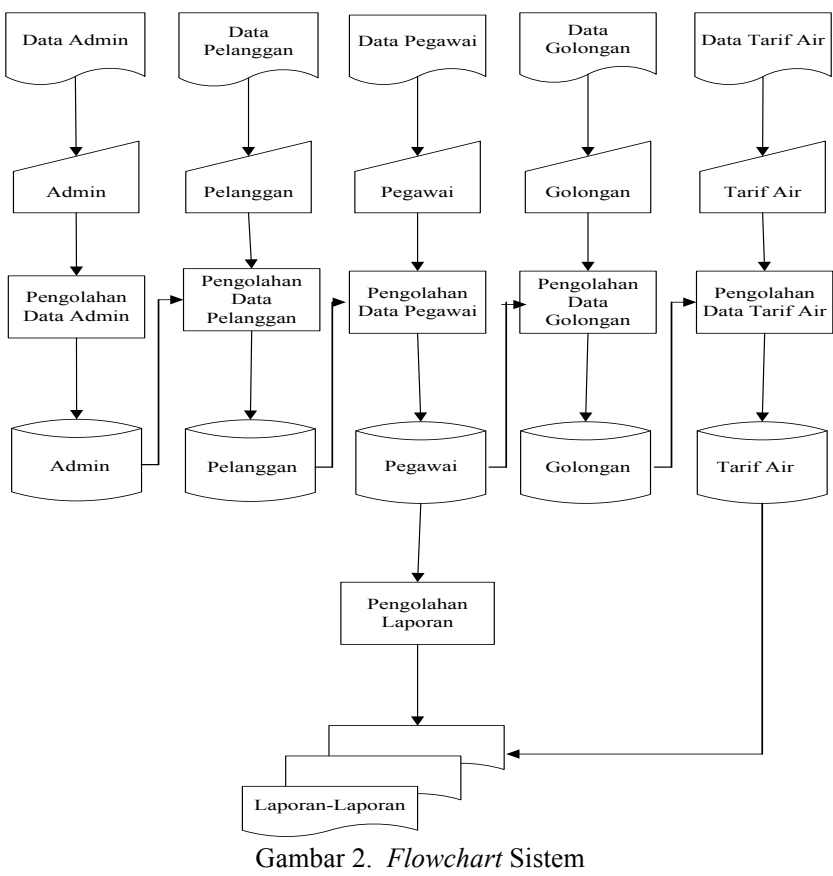

Pada kegiatan analisis bertujuan untuk memenuhi kebutuhan terhadap pemakai sistem dan memberikan gambaran yang jelas dari sistem yang akan dibangun menggunakan Microsoft Visual Studio 2010 dan MySQL sebagai Database dalam bentuk form.

Langkah-langkah dasar yang dilakukan oleh penulis adalah :

a. Mengidentifikasi masalah (Identify)

Mengidentifikasi masalah merupakan langkah pertama yang dilakukan dalam tahap analisis sistem. Masalah dapat didefinisikan sebagai suatu pertanyaan yang diinginkan untuk dipecahkan. Masalah inilah yang menyebabkan sasaran dari sistem tidak dapat dicapai. Oleh karena itu langkah pertama yang harus dilakukan oleh analisis sistem adalah mengidentifikasi terlebih dahulu masalah-masalah yang terjadi. Perusahaan Daerah Air Minum (PDAM) Tirtauli Kota Pematangsiantar sistem akuntansi rekapitulasi pendapatan yang ada pada perusahaan tersebut masih menggunakan sistem rekapitulasi pendapatan secara manual.

b. Memahami kerja sistem yang ada (Understand)

Langkah ini dapat dilakukan dengan mempelajari secara terinci bagaimana sistem yang ada beroperasi. Diperlukan data yang dapat diperoleh dengan cara melakukan penelitian. Analisis sistem perlu mempelajari apa dan bagaimana operasi dari sistem yang ada sebelum mencoba untuk menganalisis permasalahan. Sistem Akuntansi Rekapitulasi Pendapatan pada Perusahaan Daerah Air Minum (PDAM) Tirtauli Pematangsiantar masih menggunakan Microsoft Excel dimana pada Microsoft Excel sering terjadi kesalahan dalam proses penginputannya.

c. Menganalisis Sistem (Analyze)
Berdasarkan identifikasi dan kerja sistem yang ada, selanjutnya analis sistem akan dapat melakukan analis dari hasil penelitian dengan baik untuk menemukan kelemahan dan permasalahan dari sistem yang ada. Kebutuhan sistem dalam Aplikasi Sistem Akuntansi Rekapitulasi Pendapatan pada Perusahaan Daerah Air Minum (PDAM) Tirtauli Kota Pematangsiantar ini meliputi kebutuhan software dan kebutuhan hardware yaitu :

1) Kebutuhan Software, diantaranya :

a. Microsoft Visual Basic Net sebagai aplikasi bahasa pemograman yang digunakan.

b. MySQL sebagai aplikasi database pemograman.

c. Cystal Report 8.5 sebagai aplikasi design tampilan laporan.

d. Xampp merupakan tool yang menyediakan paket perangkat lunak ke dalam satu buah paket.

2) Kebutuhan Hardware

Untuk menjadikan Perancangan Sistem Akuntansi Rekapitulasi Pendapatan pada Perusahaan Daerah Air Minum (PDAM) Tirtauli Kota Pematangsiantar menjadi sistem yang cukup mapan, maka PC yang mengoperasikan sistem ini harus berteknologi multimedia dan memiliki komponen perangkat keras minimal yaitu :

a. Processor Standart Pentium III atau yang searah dengannya.

b. Memori $128 \mathrm{MB}$.

c. Hardisk dengan kapasitas sedikitnya $1 \mathrm{~GB}$.

d. Instalasi Local Area Network (LAN), sebagai sarana dalam kegiatan sharing database.

d. Membuat laporan hasil analisis (Report)

Untuk melaksanakan penelitian ini, penulis perlu menentukan lingkup sistem dari sistem yang baru dan mendapatkan informasi yang banyak.

B. Desain Sistem

Metode perancangan sistem digunakan dalam membangun sistem diantaranya membangun rancangan proses, rancangan input, rancangan output, rancangan database, rancangan sistem dan rancangan interface.

1. Rancangan Proses

Rancangan proses dimodelkan dengan Data Flow Diagram (DFD). Rancangan DFD merupakan hal yang harus dilakukan karena dengan melihat DFD maka kita akan mengetahui arus data yang mengalir dalam suatu sistem dan mengimplementasikannya pada sebuah database.

a. Rancangan Context Diagram

Adapun perancangan Context Diagram dari perancangan Sistem Akuntansi Rekapitulasi Pendapatan Pada Perusahaan daerah Air Minum (PDAM) Tirtauli kota pematangsiantar adalah seperti gambar 14 dibawah ini: 


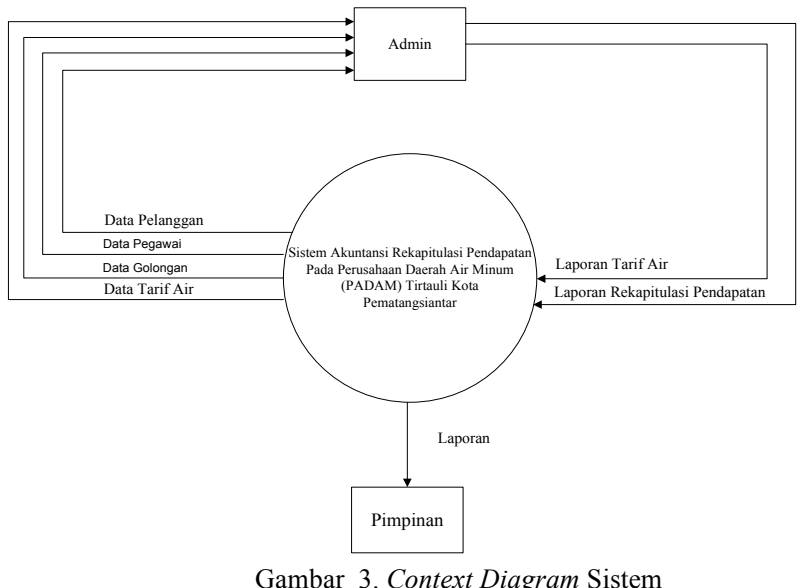

1) Admin melakukan pendataan tarif air dan mengkonfirmasikan yang akan dijadikan laporan tarif air.

2) Admin memberi kode golongan pada setiap perhitungan tarif air yang akan diterima.

3) Admin akan memberikan data yang diterima oleh pegawai seperti : data pelanggan, golongan tarif air, data pegawai disetiap perhitungan tairf air yang diterima.

4) Admin melakukan perhitungan tarif air dan mencatat hasil perhitungan.

5) Admin akan mengumpulkan seluruh data perhitungan tarif air yang dilakukan pegawai dan merekap beberapa hasil perhitungan tarif air setiap bulan.

6) Admin akan mencetak laporan tarif air dan rekapitulasi pendapatan berdasarkan perhitungan yang diterima pegawai.

7) Pimpinan akan mendapat laporan tarif air dan rekapitulasi pendapatan setiap bulan.

b. Rancangan DFD Level 1

Adapun rancangan DFD level 1 dari perancangan

Sistem Akuntansi Rekapitulasi Pendapatan pada Perusahaan Daerah Air Minum (PDAM) Tirtauli kota Pematangsiantar seperti gambar 15 dibawah ini :

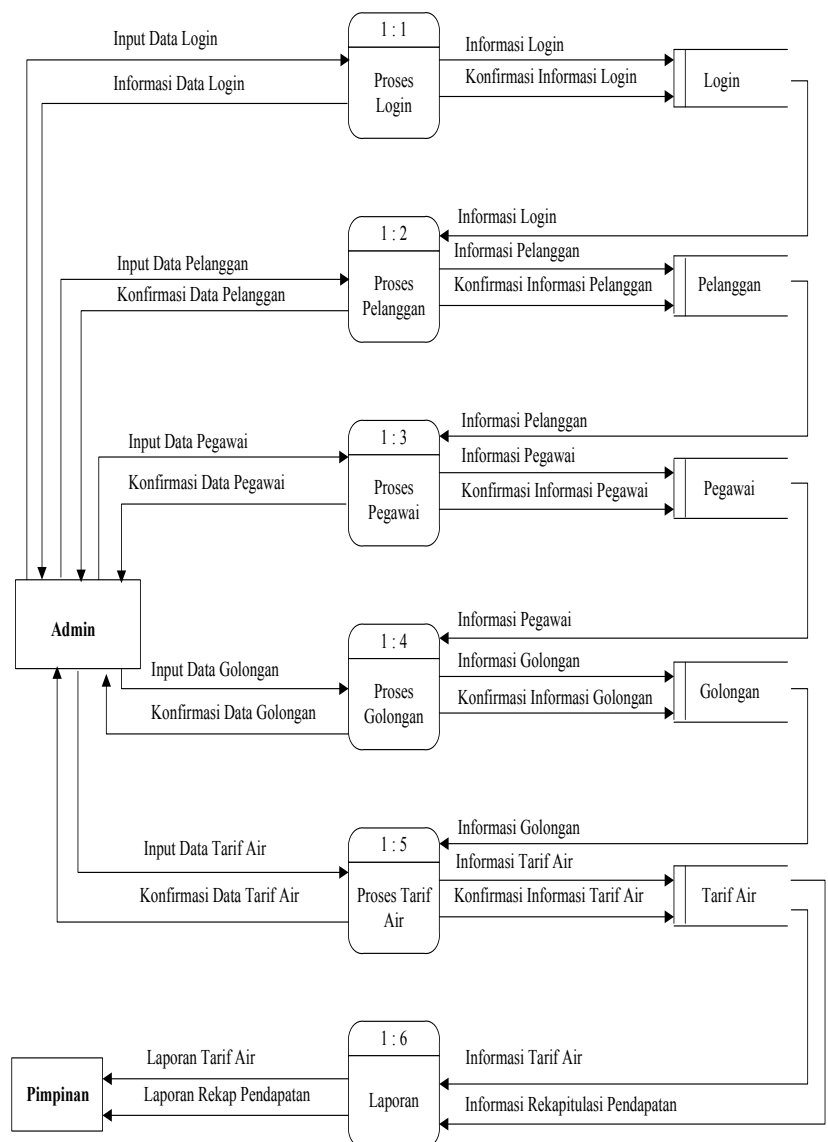

Gambar 4. Data Flow Diagram (DFD) Level 1

1) Proses Login

Pada proses mengolah Data Login, Admin akan melakukan login sebagai admininstrasi. Selanjutnya Data Login tersebut akan dikonfirmasi kepada Admin.

2) Proses Mengolah Data Pelanggan

Pada proses mengolah Data Pelanggan, admin memasukkan Data Pelanggan yang akan diteruskan ke proses mengolah Data Pelanggan. Selanjutnya disimpan pada Tabel Pelanggan. Selanjutnya Data Pelanggan tersebut akan dikonfirmasi kepada admin.

3) Proses Mengolah Data Pegawai

Pada proses mengolah Data Pegawai, admin memasukkan Data Pegawai yang akan diteruskan ke proses mengolah Data Pegawai. Selanjutnya Data Pegawai disimpan pada Tabel Pegawai. Selanjutnya Data Pegawai tersebut akan dikonfirmasi kepada admin.

4) Proses Mengolah Data Golongan

Pada proses mengolah Data Golongan, admin memasukkan Data Golongan yang akan diteruskan ke proses mengolah Data Golongan. Selanjutnya Data Golongan disimpan pada Tabel Golongan. Selanjutnya Data Golongan tersebut dikonfirmasi kepada admin.

5) Proses Mengolah Data Tarif 
Pada proses mengolah Data Tarif Air, admin memasukkan Data Tarif Air yang akan diteruskan ke proses mengolah Data Tarif Air. Selanjutnya Data Tarif Air disimpan pada Tabel Tarif Air. Selanjutnya Data Tarif Air tersebut dikonfirmasi kepada admin.

6) Proses Mengolah Data Laporan Tarif Air

Pada proses mengolah Data Laporan Tarif Air, admin telah menerima Data oleh petigas Input Data Tarif Air dan telah memasukkan data ke Tabel Tarif Air. Selanjutnya admin akan menerukan ke proses mengolah Laporan Tarif Air. Selanjutnya Laporan Tarif Air yang dihasilkan diserahkan kepada Pimpinan.

7) Proses Mengolah Data Laporan Rekapitulasi Pendapatan

Pada proses mengolah data rekapitulasi laporan pendapatan, admin telah menerima data oleh pegawai berdasarkan input data rekap pendapatan dan telah memasukkan data ke tabel rekap pendapatan selanjutnya admin akan meneruskan ke proses mengolah laporan rekapitulasi pendapatan. Selanjutnya laporan rekapitulasi pendapatan yang dihasilkan dikirim kepada pimpinan.

\section{Rancangan Masukan (Input)}

Rancangan masukan (input) merupakan rancangan yang dibutuhkan oleh sistem yang dirancang untuk memasukkan data (input). Perancangan sistem akuntansi rekapitulasi pendapatan pada Perusahaan Daerah Air Minum (PDAM) Tirtauli Pematangsiantar.
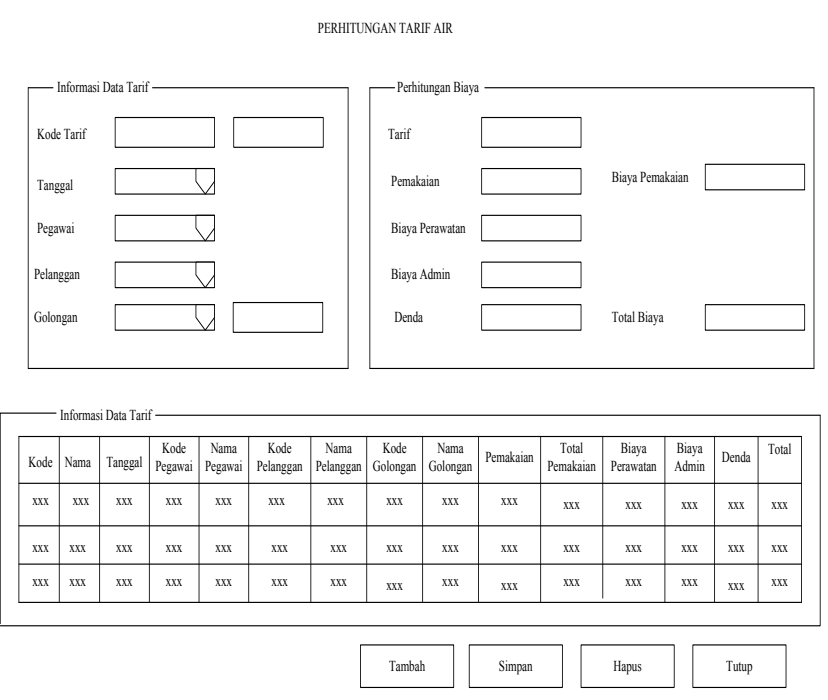

Gambar 5. Rancangan Masukan (Input)

\section{Rancangan Keluaran (Output)}

Rancangan keluaran merupakan rancangan laporan tarif air yang dihasilkan oleh sistem yang dirancang. Dibawah ini adalah gambaran dari rancangan keluaran (output) rancangan sistem akuntansi rekapitulasi pendapatan pada Perusahaan Daerah Air Minum (PDAM) Tirtauli Pematangsiantar.

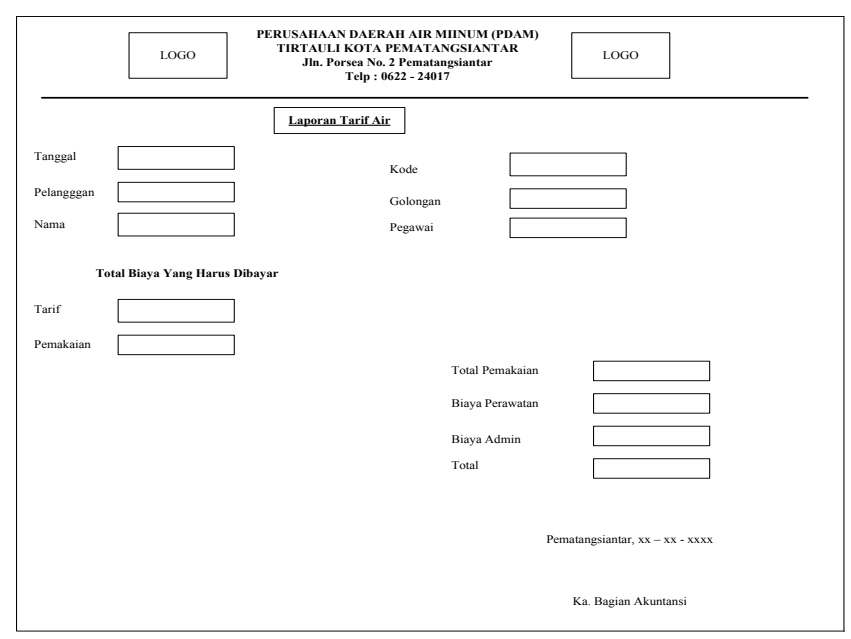

Gambar 6.Rancangan Keluaran (Output) Laporan Tarif Air

\section{Rancangan Database}

\section{a. Normalisasi}

Berikut tahapan-tahapan normalisasi yang sesuai dengan kasus yang akan diimplementasikan.

Unnormalisasi

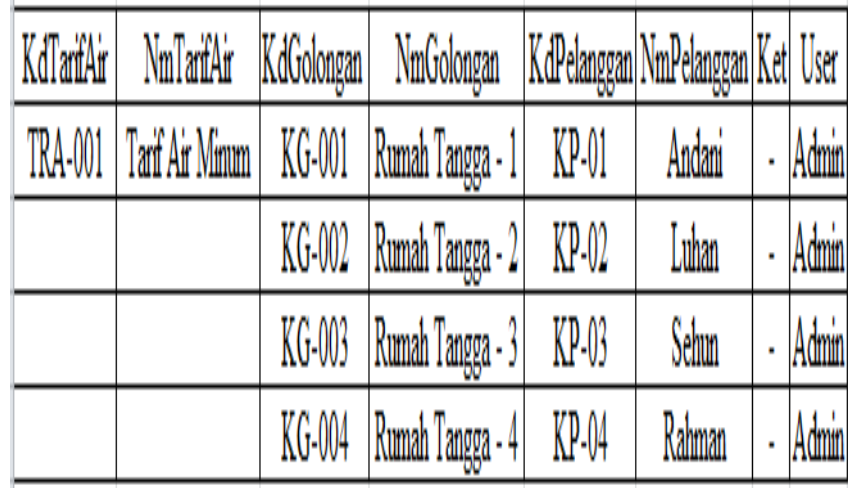

Gambar 7. Bentuk Unnormalisasi

Normalisasi merupakan suatu cara untuk mengorganisasikan data kedalam bentuk tabel-tabel untuk mengetahui dan memenuhi kebutuhan dari suatu organisasi.

1) Normal Pertama $\left(1^{\text {st }} \mathrm{NF}\right)$

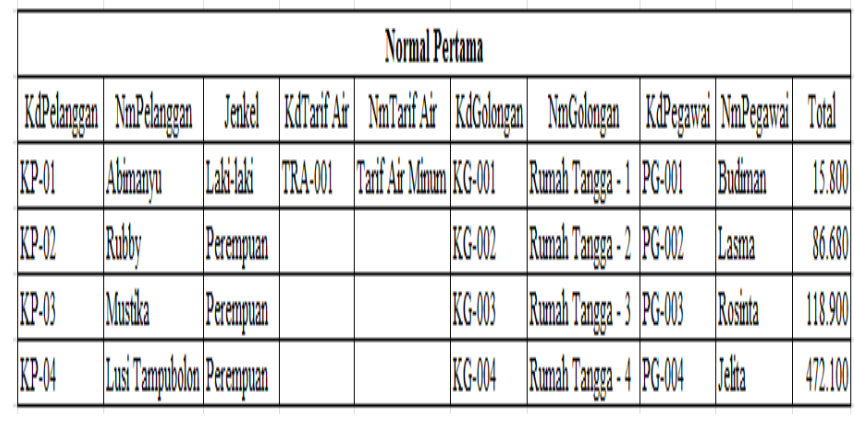

Gambar 8. Bentuk Normal Pertama ( $\left(1^{\text {st }} \mathrm{NF}\right)$

Suatu tabel dikatakan berada pada bentuk normal 1 jika ia tidak berada pada bentuk unnormalized table, dimana terjadi 
penggandaan field yang sejenis dan memungkinkan ada field yang null (kosong).

2) Normal Kedua $\left(2^{\text {nd }} N F\right)$

\begin{tabular}{|l|l|l|l|l|}
\hline \multicolumn{5}{|c|}{ Normal Kedua } \\
\hline KdPelanggan & NmPelanggan & & KdGolongan & NinGolongan \\
\hline KP-01 & Amri & & KG-001 & Rumah Tangga - 1 \\
\hline KP-02 & Chiko & KG-002 & Rumah Tangga - 2 \\
\hline KP-03 & Delima & KG-003 & Rumah Tangga - 3 \\
\hline KP-04 & Shifah & KG-004 & Rumah Tangga - 4 \\
\hline \multicolumn{3}{|l|}{} \\
Kd-Pegawai & NmPegawai & KdTarifAir & NmTarifAir \\
\hline PG-001 & Bintang & TRA-001 & Tarif Air Minum \\
\hline PG-002 & Budiman & & \\
\hline PG-003 & Rosinta & & \\
\hline PG-004 & Lasma & & \\
\hline
\end{tabular}

Gambar 9. Bentuk Normal Kedua ( $\left.2^{\text {nd }} \mathrm{NF}\right)$

Suatu tabel dikatakan berada pada bentuk normal 2 jika:

Memenuhi kriteria tabel Normal $1\left(1^{\text {st }} \mathrm{NF}\right)$, di dalam tabel tersebut ada Redudansi/ pengulangan data dan null value, Field-field yang bukan PK adalah Full Dependent (bergantung penuh) pada PK.

3) Normal Ketiga $\left(3^{\text {th }} \mathrm{NF}\right)$

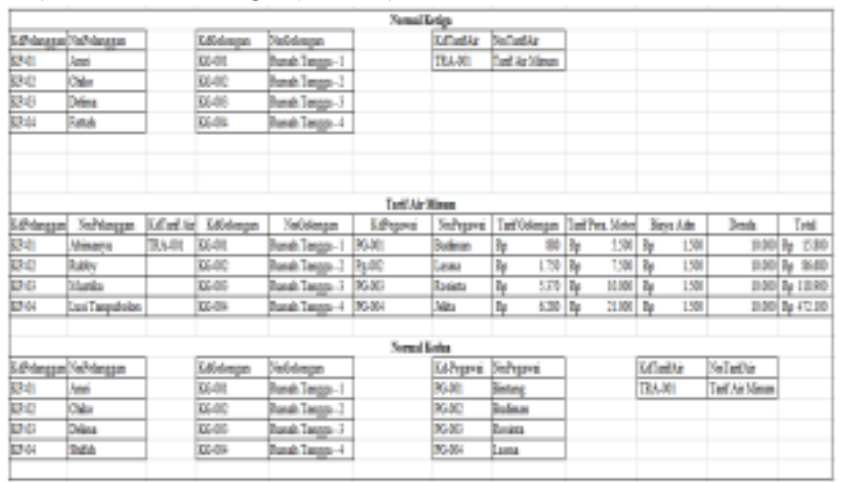

Gambar 10. Bentuk Normal Ketiga $\left(3^{\text {th }} \mathrm{NF}\right)$

Suatu relasi $\mathrm{R}$ dikatakan berada pada bentuk normal 3 jika : Berada dalam bentuk normal $2^{\text {nd }} \mathrm{NF}$ dan tidak dijumpai adanya ketergantungan transitif (Transitive Dependency), ketergantungan transitif (Transitive Dependency) adalah ketergantungan fungsional antara 2 (atau lebih) atribut bukan key (kunci).

\section{Relasi Antar Tabel (RAT)}

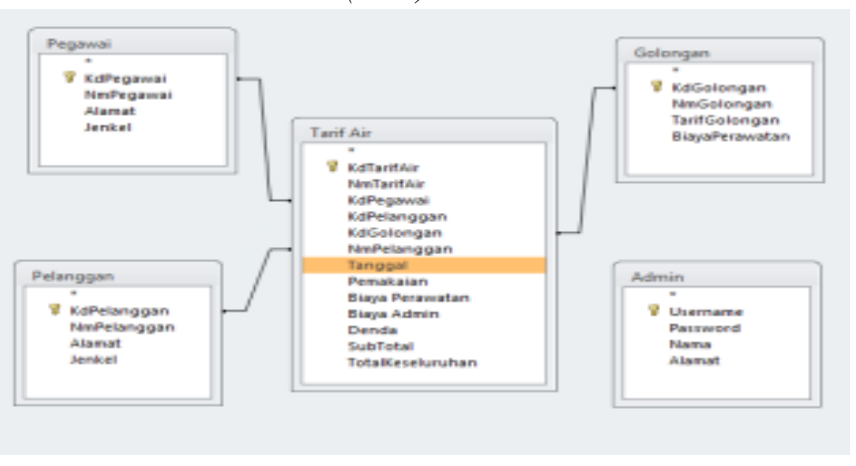

Gambar 11. Relasi Antar Tabel

\section{Entity Relational Diagram}

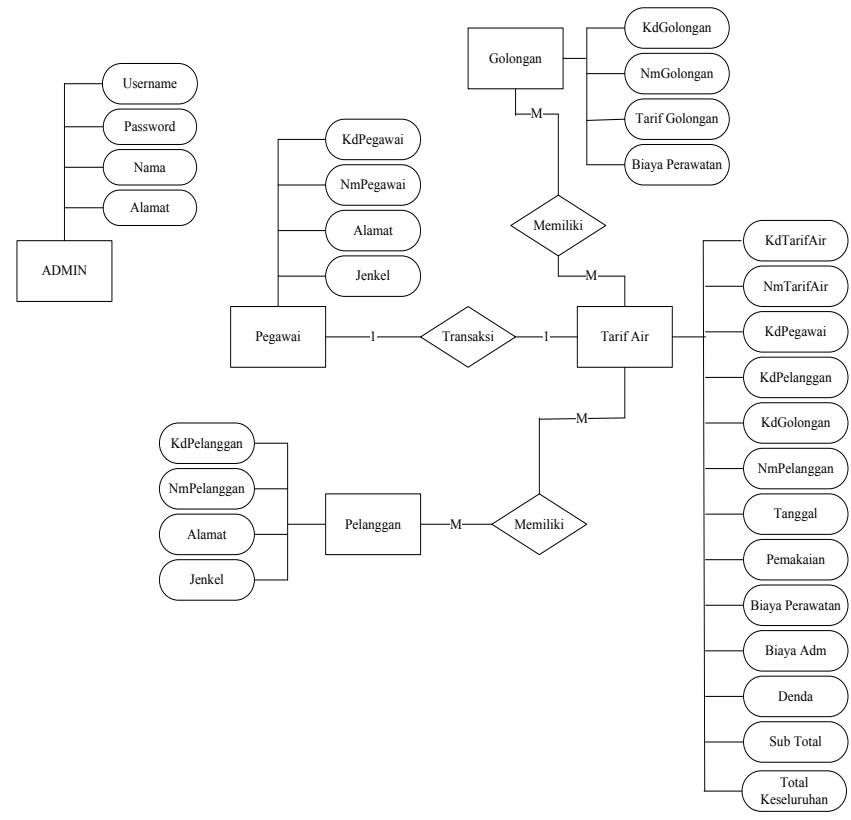

Gambar 12. Entity Relational Diagram (ERD)

Bentuk dari Entity Relational Diagram dari perancangan sistem akuntansi rekapitulasi pendapatan pada Perusahaan Daerah Air Minum (PDAM) Tirtauli kota pematangsiantar adalah seperti gambar 12 .

\section{Implementasi Sistem}

Sistem yang sudah dirancang selanjutnya akan diteruskan ke tahap pengimplementasian. Sebelum masuk ke menu utama dari Perancangan Sistem Akuntansi Rekapitulasi Pendapatan pada Perusahaan Daerah Air Minum (PDAM) Tirtauli Pematangsiantar menggunakan Visual Basic Net dan Database MySQL ini dimulai dengan munculnya form koneksi dan login yang berfungsi untuk keamanan sistem seperti pada gambar 13 berikut ini:

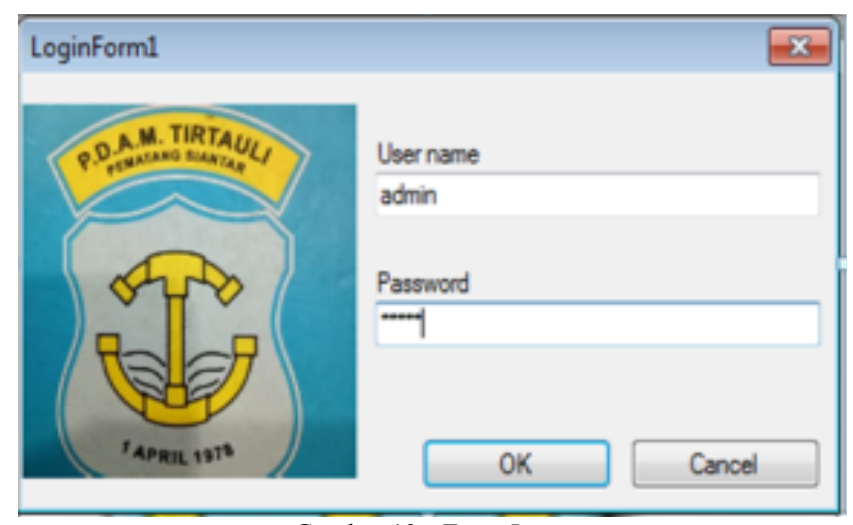

Gambar 13. Form Login

Klik tombol OK untuk menyesuaikan data username dan password. Apabila data sudah sesuai maka selanjutnya akan masuk kedalam tampilan menu utama. Tampilan 
form menu utama dapat dilihat pada gambar 14 dibawah ini:

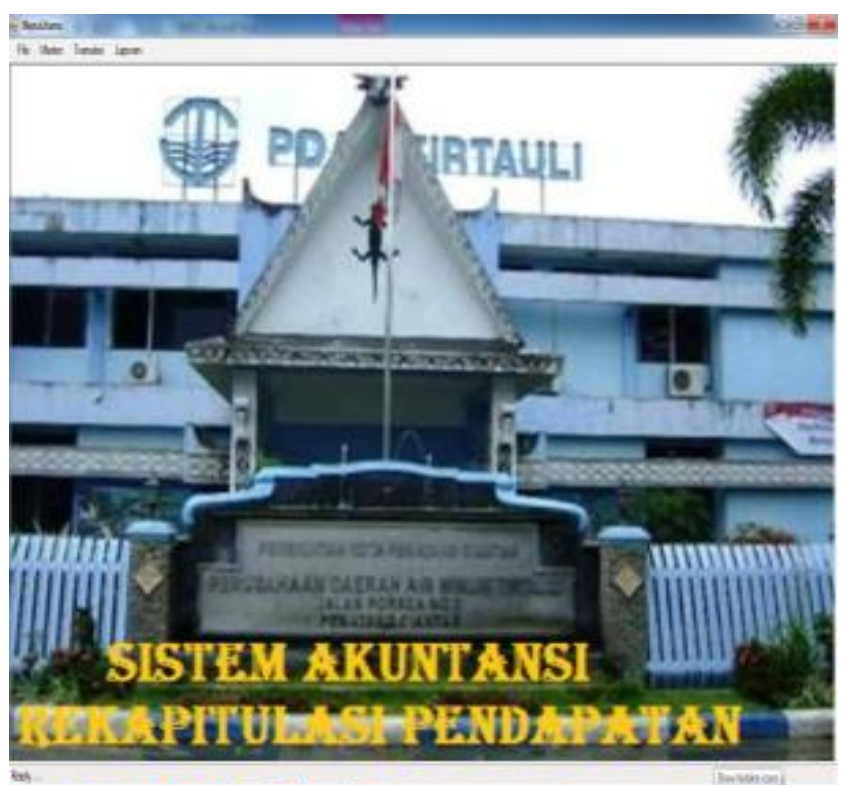

\section{Masukan (Input) Sistem}

Gambar 14. Form Menu Utama

Masukan (input) sistem ini digunakan untuk memasukkan data kedalam sistem. Adapun form form untuk masukan (input) sistem adalah sebagai berikut:

\section{a. Form Data Pelanggan}

Form data pelanggan dapat dijalankan dengan memilih menu pada form utama, kemudian pilih data pelanggan, maka form data pelanggan akan tampil. Tampilan form data pelanggan dapat dilihat pada gambar 15 berikut ini :

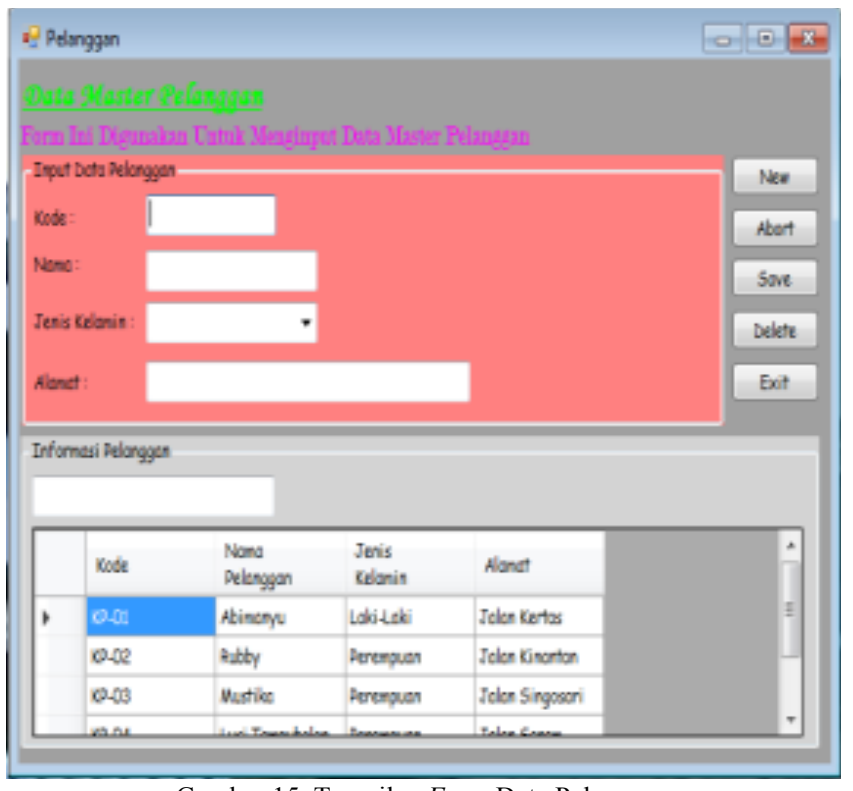

Gambar 15. Tampilan Form Data Pelanggan

b. Form Data Pegawai
Form pegawai dapat dijalankan dengan memilih menu pada form utama, kemudian pilih pegawai, maka form pegawai akan tampil. Tampilan form pegawai dapat dilihat pada gambar 16 berikut ini :

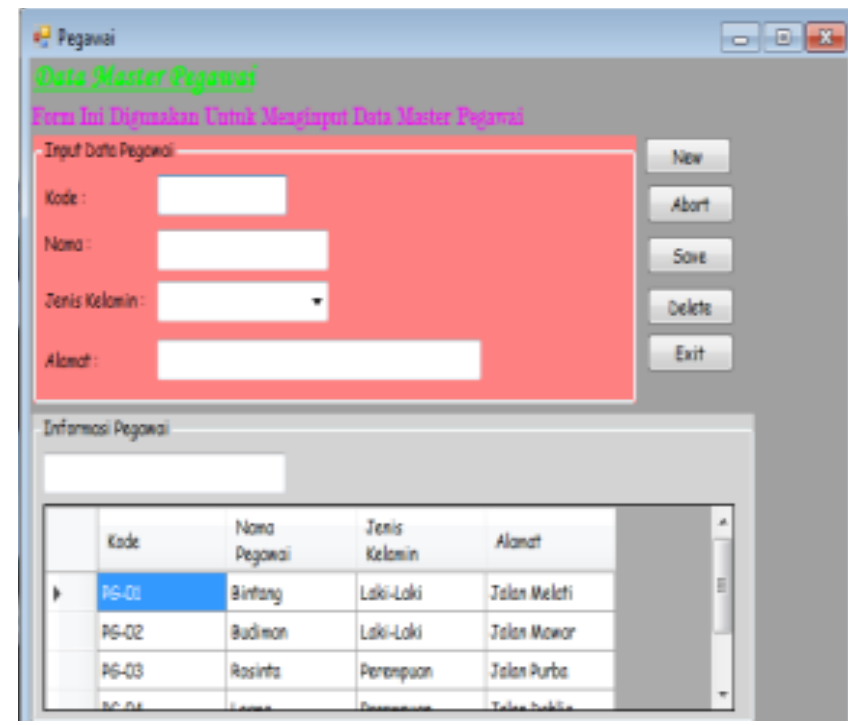

Gambar 16. Tampilan Form Data Pegawai

c. Form Data Golongan

Form data golongan dapat dijalankan dengan memilih menu pada form utama, kemudian pilih data golongan, maka form data golongan akan tampil. Tampilan form data golongan dapat dilihat pada gambar 17 dibawah ini :

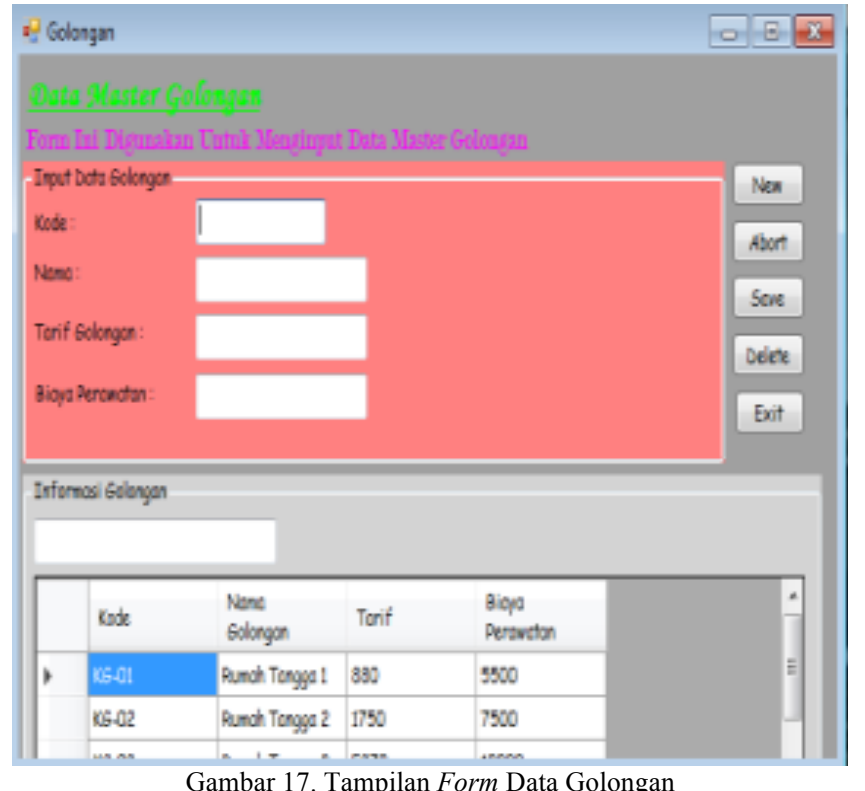

d. Form Tarif Air Minum

Form data tarif air minum dapat dijalankan dengan memilih menu pada form utama, kemudian pilh data tarif air minum, maka form tarif air minum akan tampil. Tampilan formi data tarif air minum dapat dilihat pada gambar 18 berikut ini: 


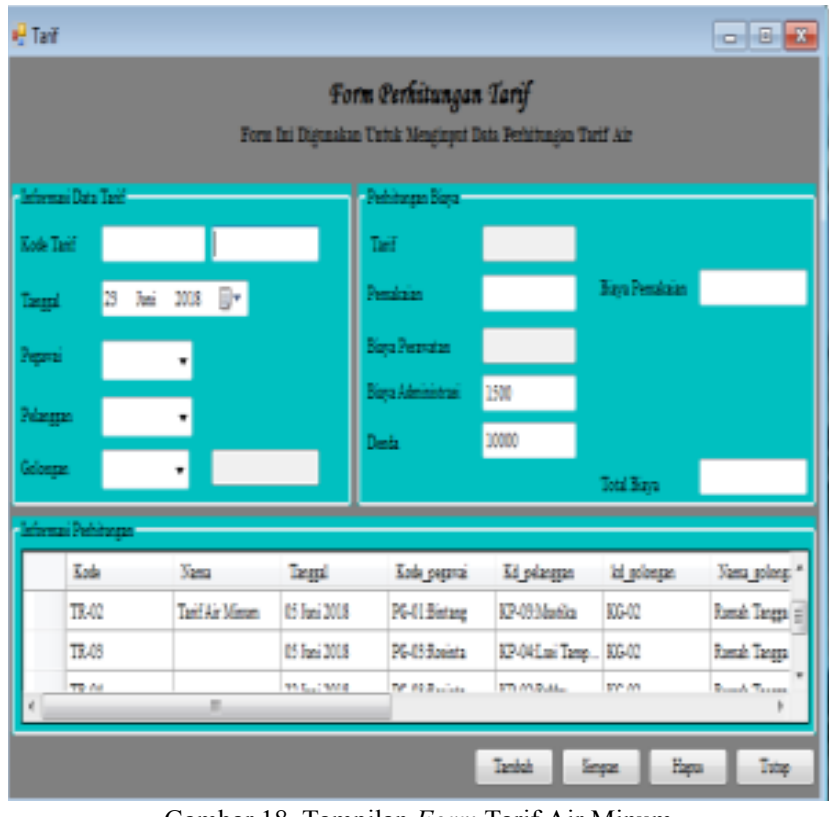

Gambar 18. Tampilan Form Tarif Air Minum

\section{Keluaran (Output) Sistem}

Keluaran (output) sistem berfungsi sebagai laporan yang dapat dicetak dari data yang telah di input. Tampilan di output sistem ini dapat dilihat dibawah ini :

a. Form Cetak Laporan \& Output Data Tarif Air Minum

Form cetak laporan data tarif air minum dapat dijalankan dengan memilih menu pada form utama, kemudian pilih cetak laporan tarif air minum, maka form cetak laporan data tarif air tampil. Tampilan form data tarif air minum dapat dilihat pada gambar 19 dan 20 dibawah ini :

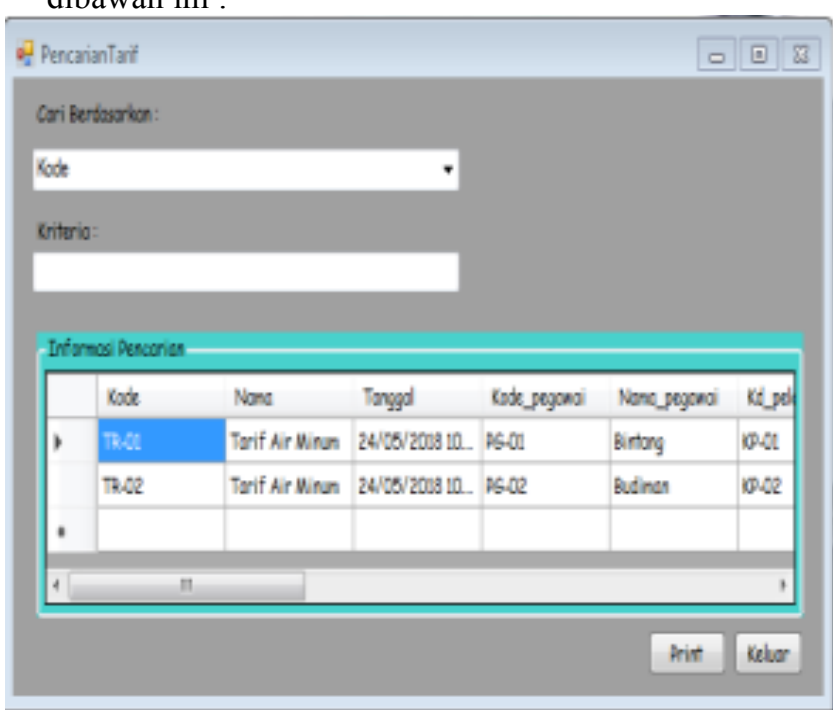

Gambar 19. Tampilan Form Cetak Laporan Tarif Air Minum

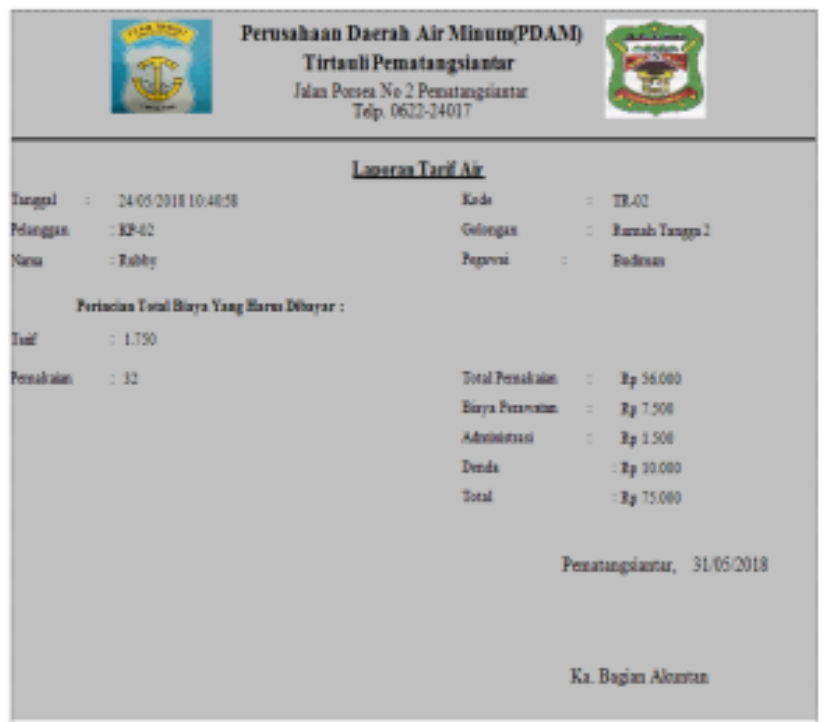

Gambar 20. Tampilan Output Laporan Tarif Air Minum

b. Form Cetak Laporan \& dan Output Rekapitulasi Pendapatan

Form cetak laporan data rekap pendapatan dapat dijalankan dengan memilih menu pada form utama, kemudian pilih cetak laporan, maka form cetak laporan data rekap pendapatan tampil. Tampilan form data rekap pendapatan dapat dilihat pada gambar 21 dan 22 dibawah ini:

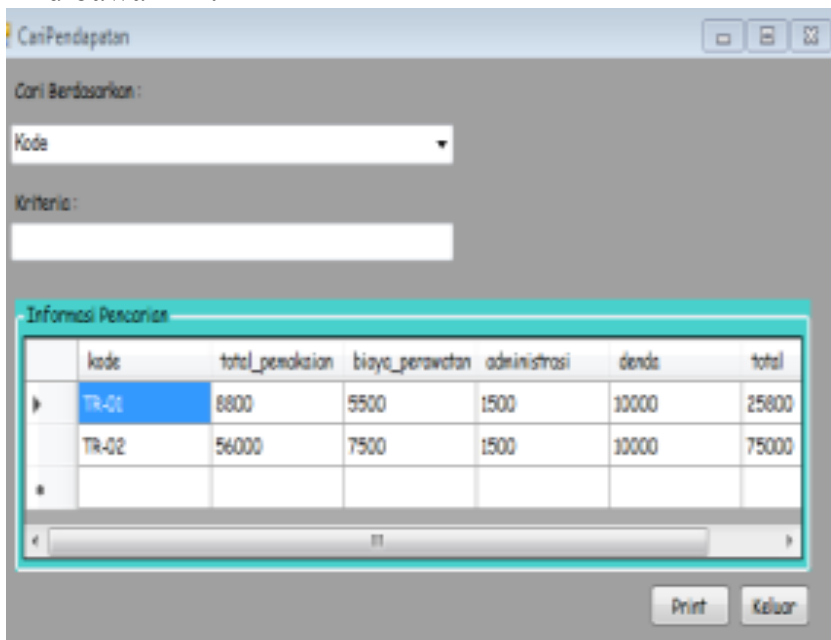

Gambar 21. Tampilan Form Cetak Laporan Rekap Pendapatan 


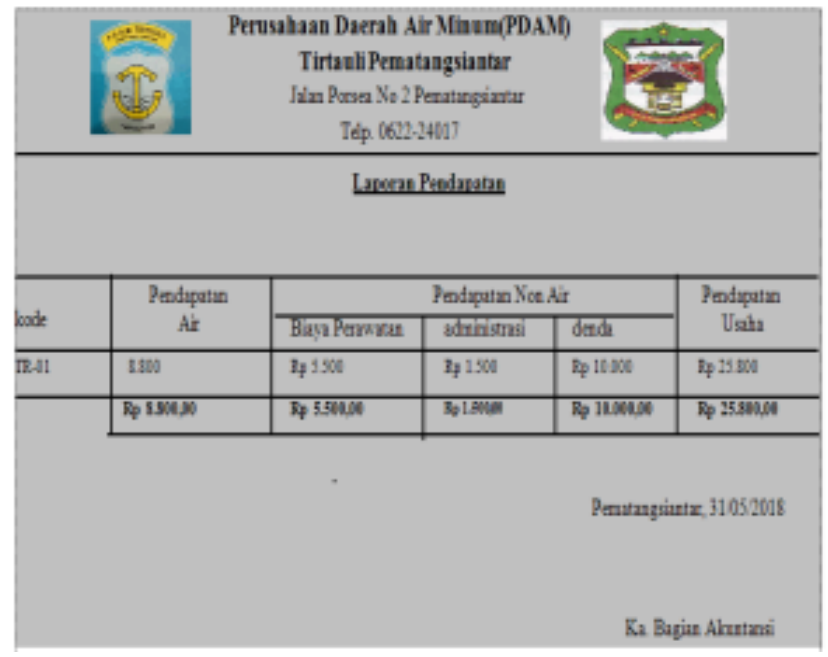

Gambar 22. Tampilan Output Laporan Rekap Pendapatan

\section{Testing Sistem}

Pengujian sistem bersifat fungsional sistem. Pada penelitian ini ujicoba sistem menggunakan metode black box untuk menguji dan menilai fungsional sistem. Uji coba ini dilakukan dengan cara memasukkan data pada isian pada menu master dan menu transaksi. Black Box merupakan metode pengujian perangkat lunak yang digunakan oleh user untuk menguji perangkat lunak tanpa mengetahui struktur internal kode atau program.

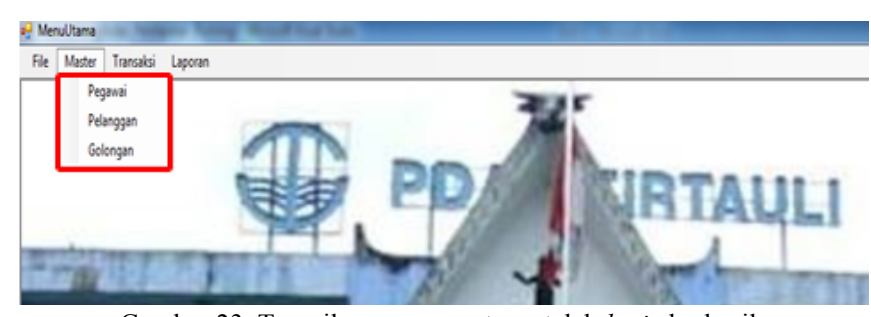

Gambar 23. Tampilan menu master setelah login berhasil
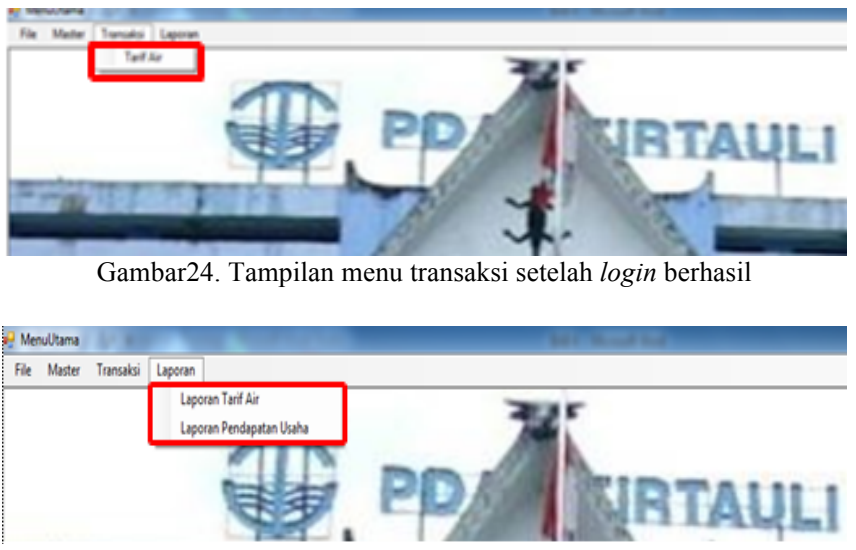

Gambar 25. Tampilan menu laporan setelah login berhasil

\section{E. Pemeliharaan Sistem}

Pemeliharaan merupakan semua aktivitas termasuk menjaga perangkat untuk selalu dapat dijalankan. Pemeliharaan adalah kegiatan memelihara atau menjaga fasilitas/peralatan dan mengadakan perbaikan atau pergantian yang diperlukan agar sesuai dengan apa yang telah direncanakan. Tujuan pemeliharaan antara lain memperpanjang masa penggunaan. Melaksanakan pemeliharaan sarana pemrograman dapat menghemat waktu, biaya dan material karena terhindar dari kerusakan besar dan kerugian baik material maupun perangkat lainya oleh karena itu kerusakan dapat dihindari sedini mungkin, karena terjadinya kerusakan dan atau timbulnya kerusakan tambahan akibat kerusakan awal untuk dapat segera dicegah. Ada 3 alasan perlunya pemeliharaan sistem, yaitu:

1. Membenarkan kesalahan atau kelemahan sistem yang tidak terdeteksi pada saat pengujian.

2. Memembuat sistem up to date

3. Meningkatkan kemampuan sistem

Adapun kelemahan Aplikasi Sistem Akuntansi Rekapitulasi Pendapatan pada Perusahaan Daerah Air Minum (PDAM) Tirtauli Pematangsiantar adalah sistem hanya dapat digunakan untuk local dan sistem tidak bersifat online sedangkan kelebihan dari sistem ini akan mempercepat dan mempermudah dalam mengolah data tarif air minum dan rekapitulasi pendapatan.

\section{IV.KESIMPULAN}

Berdasarkan uraian-uraian yang telah dibahas pada babbab sebelumnya, maka penulis dapat menyimpulkan beberapa kesimpulan yaitu:

1. Aplikasi yang akan dibangun menyajikan sistem aplikasi berbasis Interface sehingga menarik untuk dilihat.

2. Sistem ini dibangun dengan meggunakan Microsoft Visual Basic Net serta Database MySQL sehingga tidak memerlukan alat-alat sistem secara manual seperti pencatatan.

3. Output yaitu berupa laporan tarif air dan rekapitulasi pendapatan.

Beberapa saran yang dapat penulis berikan yang kiranya dapat diimplementasikan demi meningkatkan proses kinerja Sistem Aplikasi yang diantaranya:

1. Menjaga kerahasiaan akun, demi terjaganya rahasia data pengguna di dalam sistem.

2. Melakukan uju coba terhadap sistem sebelum sistem ini dipublikasikan dan digunakan.

3. Melakukan pengembangan-pengembangan dan revisi terhadap sistem, sehingga kedepannya dapat berjalan dengan lebih optimal dan lebih kompleks.

4. Mengadakan beberapa pelatihan singkat bagi pengguna sistem.

5. Melakukan perawatan dan pemeliharaan sistem.

\section{DAfTAR Pustaka}

[1] E.B. Sasongko, E. Widyastuti, and R. E. Priyono, "Kajian Kualitas Air dan Penggunaan Sumur Gali oleh Masyarakat di Sekitar Sungai Kaliyasa Kabupaten Cilacap," J. Ilmu Lingkung, vol. 12, no. 2, pp. 7282, 2014.

[2] M.C. Sustandi, "Penelitian Air Bersih di PT Summit Plast Cikarang," J. Tek. Sipil, vol. 8, no. 2, pp. 133-141, 2012. 
[3] 33 Pasal, 3 Ayat and 1945 UUD, Undang-Undang Dasar Negara Republik Indonesia Tahun 1945.

[4] Menteri dalam Negeri, Peraturan Menteri dalam Negri Nomor 2 Tahun 2007 tentang Organ dan Kepegawaian Perusahaan Daerah Air Minum., 2007, pp. 1-11.

[5] PP RI No. 122 Tahun 2015, Tentang Sistem Penyediaan Air Minum.

[6] Peraturan Menteri dalam Negeri Nomor 23 Tahun 2006, Peraturan Menteri dalam Negeri Nomor 23 Tahun 2006 tentang Pedoman Teknis dan Tata Cara Pengaturan Tarif Air Minum pada Perusahaan Daerah Air Minum.

[7] Y. Wardany, D. Suhendro, and F. A. Purba, "Sistem Pehitungan PPH Pasal 21 atas Pembayaran Gaji Pegawai Kantor pada PT Perkebunan Nusantara III Sei Mangkei Kabupaten Simalungun," TECHSI, vol. 11, no. 1, pp. 157-168, 2019.

[8] A. Nizhar, D. Suhendro, and R. J. J. M. T. P, "Sistem Informasi Pembayaran Premi Semprot Pada PTPB IV Unit Kebun Laras Serbelawan Kabupaten Simalungun," TECHSI, vol. 11, no. 1, pp. 1524, 2019.

[9] A. Triani, "Creative Accounting Sebagai Informasi yang Baik atau Menyesatkan," J. Akunt, vol. 8, no. 2, pp. 103-111, 2017.

[10] C. R. F. Worotitjan and J. Morassa, "Analisis Perhitungan Biaya Produksi pada PT Manado Nusantara Informasi (Koran Sindo)," $J$. Ris. Ekon. Manajemen, Bisnis dan Akut, vol. 4, no. 1, pp. 974-981, 2016. 